\title{
IgG and IgG Subclass Specific Antibody Responses to Diphtheria and Tetanus Toxoids in Newborns and Infants Given DTP Immunization
}

\author{
JOAN DENGROVE, EUI JUNG LEE, DOUGLAS C. HEINER, JOSEPH W. St. GEME, Jr., \\ ROSEMARY LEAKE, LARRY J. BARAFF, AND JOEL I. WARD \\ Department of Pediatrics, Divisions of Infectious Diseases and Immunology/Allergy, Harbor-UCLA Medical \\ Center, UCLA Medical Center and UCLA School of Medicine, Torrance and Los Angeles, California
}

\begin{abstract}
To evaluate immune responses to diphtheria and tetanus toxoids in infants we used enzyme-linked immunosorbent assays to detect total IgG and specific IgG1, IgG-2, IgG-3, and IgG-4 antibody. One group of infants received a newborn dose and subsequently received the usual three doses of DTP. A second group of infants received only the routine dosage at 2,4 , and 6 months of age. In sera acquired at birth, 6 , and 9 months of age, there were no statistically significant differences between the two vaccine groups in IgG antibody responses to diphtheria or tetanus, or in IgG subclass tetanus-specific antibody responses. In individual children, tetanus-specific subclass responses were similar in pattern to that for total IgG tetanus antibody, i.e. each IgG subclass response appeared to be regulated by similar mechanisms in that child, but the regulation differed between children. In contrast to a prior study of pertussis immunity, maternally acquired antibody did not significantly affect immune responses to diphtheria or tetanus toxoid by 9 months of age. There was no discernible tolerance due to early tetanus or diphtheria immunization or to high levels of maternally acquired antibody. (Pediatr Res 20: 735-739, 1986)
\end{abstract}

\section{Abbreviations}

$\mathrm{RD}$, routine dosage

$\mathrm{ND}$, neonatal dosage

ELISA, enzyme-linked immunosorbent assays

PBST, phosphate-buffered saline with $0.05 \%$ Tween 20

RT, room temperature

LF, limit flocculation

GMT, geometric mean titer

In an earlier study, we evaluated the immune responses to pertussis in neonates given an additional dose of DTP vaccine in the newborn nursery (1). The study was originally undertaken to evaluate the potential benefit of neonatal immunization prior to nursery discharge for immigrant population groups with low immunization rates. It was demonstrated that an early neonatal dose of DTP resulted in a lowered pertussis antibody response in the subgroup of infants who had low maternally acquired levels of antibody. This suggested the possibility of tolerance

Received August 16, 1985; accepted March 24, 1986.

Correspondence and reprint requests to Joel I. Ward, M.D., Pediatric Infectious Diseases, 1124 Carson Street, Torrance, CA 90509.

This work was supported in part by Grants NH3928-2 and NH3974-3 from the National Institutes of Health and by a grant from the Connaught Laboratories. being induced by early immunization in at least a subgroup of infants.

The purpose of the current study was to evaluate diphtheria and tetanus antibody responses in these infants. We were also interested in characterizing subclass-specific antibody responses because little is known about subclass-specific responses in infants. In addition, we evaluated the influence of maternally acquired antibody on the total and subclass-specific immune responses.

\section{MATERIALS AND METHODS}

Subjects, immunizations, and specimens. Ninety-one healthy, full-term newborn infants (Hispanic-62\%, Caucasian-23\%, black $-10 \%$, and Asian-5\%) were prospectively enrolled during a 6-month period in 1979. They were randomly assigned to a RD group or a ND group. The RD group received intramuscular injections of DTP vaccine $(0.5 \mathrm{ml}$, Wyeth Laboratories) at 2,4 , and 6 months of age. The ND group received the first dose of DTP before 4 days of age in addition to the usual series at 2,4 , and 6 months of age. Sera were obtained at birth from the umbilical cord and then from infants at 6 and 9 months of age. All sera were frozen at $-20^{\circ} \mathrm{C}$ until antibody assays were performed. For this study, 28 sets of sera acquired at birth, 6 and 9 months were available for evaluation (15-ND, 13-RD). One set of sera from the ND group analyzed for diphtheria antibody was not sufficient in amount to be analyzed for tetanus antibody.

Antibody assays. IgG-specific diphtheria and tetanus antibody levels and $\mathrm{IgG}$ subclass-specific tetanus antibody levels were measured by ELISA. For the diphtheria antibody measurements, microtiter trays (Immunlon II, Dynatech) were coated for $2 \mathrm{~h}$ at $37^{\circ} \mathrm{C}$ with $375 \mathrm{ng} / \mathrm{ml}$ of diphtheria toxoid $(0.135 \mathrm{LF} / \mathrm{ml})$. The plates were then washed with PBST three times and serial dilutions of sera were added to duplicate wells. The plates were incubated overnight at $4^{\circ} \mathrm{C}$ and washed an additional three times. Goat antihuman IgG (Atlantic Antibodies) conjugated with alkaline phosphatase (Sigma) was then added to the wells and incubated for $4 \mathrm{~h}$ at RT in the dark. The plates were again washed three times with PBST, and substrate buffer containing $0.1 \%$ p-nitrophenylphosphate was added for $1 \mathrm{~h}$ at RT in the dark. Optical densities were measured with a Titertek Multiskan (Flow Laboratories) at $405 \mathrm{~nm}$. The standard reference serum used in these assays was obtained from an adult with the highest relative diphtheria antibody found from screening adult serum samples. Buffer as well as serum with no detectable antibodies were included in each assay as negative controls. Agammaglobulinemic sera also had no detectable reaction. All assays were performed in duplicate. Diphtheria antibody units were quantitated by the method of Zollinger and Bostego (2).

The total IgG antitetanus antibody was measured in an ELISA 
similar to the IgG diphtheria ELISA, except that the plates were coated with tetanus toxoid $(50 \mathrm{ng} / \mathrm{ml}, 0.025 \mathrm{LF} / \mathrm{ml})$, kindly provided by the Massachusetts Biologic Laboratories. Human tetanus immunoglobulin (Travenol HU-TET, $250 \mathrm{U} / \mathrm{vial}$ ) in serial dilutions was used as the standard positive control, and buffer as well as serum with no detectable antibodies as negative controls. These all had equivalent negative values which were less than the lowest value on the corresponding standard curve. Total IgG antibody was quantitated by the method of Zollinger and Bostego (2).

The IgG subclass-specific tetanus ELISA differed from the total tetanus IgG ELISA in that microtiter trays were coated with $0.1 \mathrm{ml}$ tetanus toxoid $(0.1 \mathrm{LF} / \mathrm{ml})$ for the subclass assays and only $0.025 \mathrm{LF} / \mathrm{ml}$ for total $\mathrm{IgG}$ assays. These concentrations were shown to be optimal in preliminary assays. For subclass antibodies sera were then added to the wells and incubated for 2 $\mathrm{h}$ at $37^{\circ} \mathrm{C}$ followed by three washes. Monoclonal mouse antihuman IgG subclass-specific antibodies (Seward) were then added to the wells and incubated overnight at $4^{\circ} \mathrm{C}$, followed by the addition of rabbit antimouse $\mathrm{IgG}$ conjugated with alkaline phosphatase (Sigma) for $1 \mathrm{~h}$ at $37^{\circ} \mathrm{C}$. Finally, substrate buffer containing $0.1 \%$-nitrophenylphosphate was added for $1 \mathrm{~h}$ at RT in the dark, and optical densities were then read. The standard positive control was obtained from an adult who was recently immunized with tetanus toxoid and demonstrated a high level of antibody for a particular IgG subclass. This control value was arbitrarily assigned a value of $4000 \mathrm{U}$, and levels of antibody for each subclass were calculated relative to this reference.

Total IgG antibodies to tetanus and diphtheria were measured on each specimen in single same day assays for each antigen. All IgG-1 values were measured in one assay, as were all $\mathrm{IgG}-2$, IgG-3, and IgG-4 values. The specificity of the monoclonal antibodies to IgG-1 was verified by demonstrating their reaction with purified G-1 myeloma protein, but not with purified G-2, G-3, or G-4 proteins. Monoclonal antibodies to the other IgG subclasses were similarly shown to react only with the corresponding myeloma protein.

Statistics. All antibody levels were log transformed for analysis. Differences in the levels of antibody between the RD and ND groups or the high and low maternal antibody groups were analyzed using the Wilcoxon Rank Sum test for nonnormalized data and the Student's $t$ test for normally distributed data (3). Tetanus subclass-specific IgG antibody levels were analyzed using the Student's $t$ test alone. Correlations between IgG tetanus antibody levels and individual subclass levels were established by analysis of repeated measurements (4).

\section{RESULTS}

Diphtheria antibody. The diphtheria IgG antibody levels in cord, 6 and 9 months blood samples for RD and ND groups are shown in Figure $1 A$. There were no significant differences between the antibody levels of the RD and the ND groups at any time point (NS, Rank Sum and $t$ test).

In as much as the immune responses to diphtheria toxoid were similar for both groups, the ND and RD groups were combined to evaluate the influence of maternal antibody. Individual cord blood titers were compared to the GMT of all cord bloods. Based on this comparison, cord blood specimens were divided into high or low maternal antibody groups $(>$ GMT or $\leq$ GMT of cord blood, respectively). Shown in Figure $1 B$ are the levels of maternally acquired antibody in the high and low groups at 0,6 , and 9 months of age. There were no significant differences in the antibody levels between the high and low groups at 6 or 9 months of age.

To evaluate a potential effect of tolerance, we compared the diphtheria immune response in the ND and the RD groups, examining only those infants born with low levels of diphtheria antibody. There were no significant differences in antibody levels
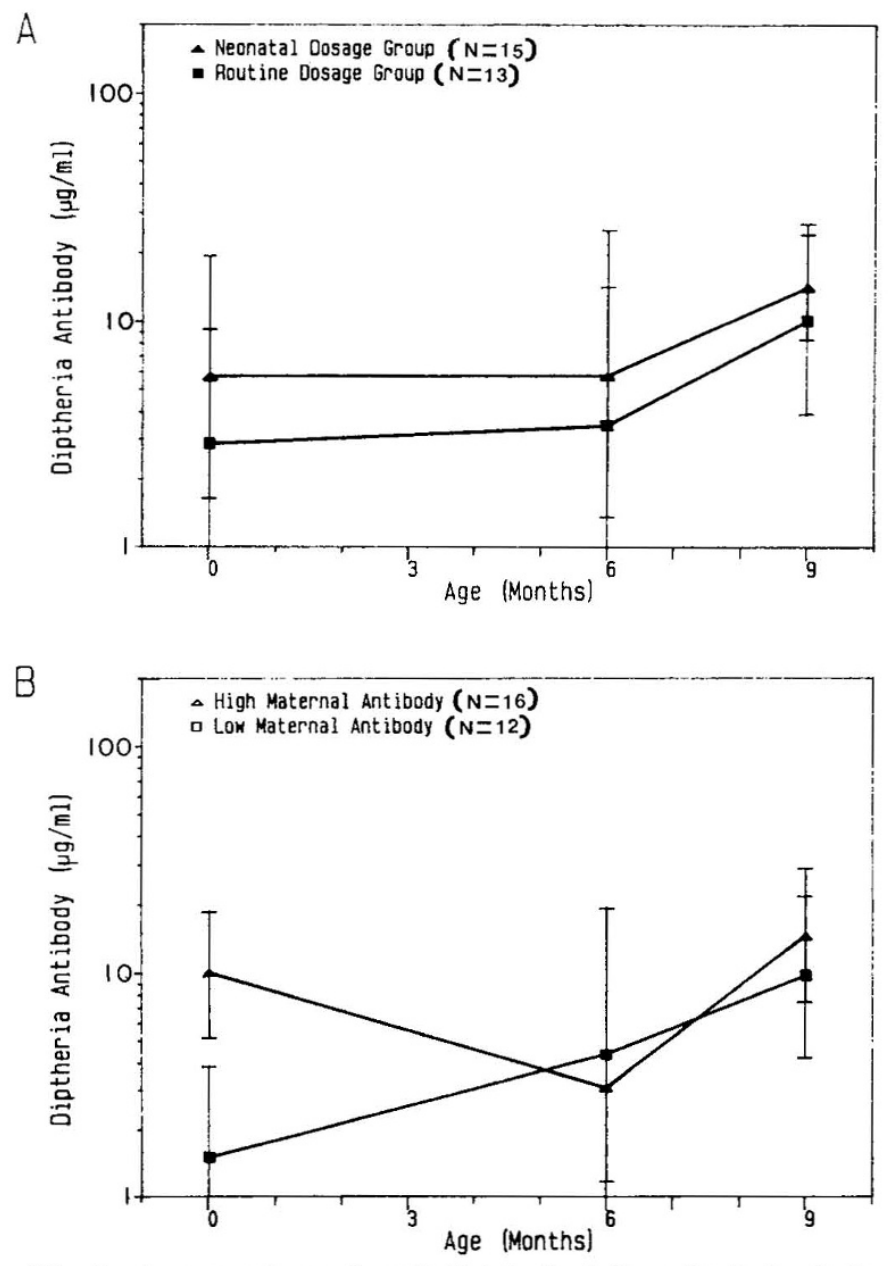

Fig. 1. A, comparison of total diphtheria IgG antibody levels in neonatal $(\boldsymbol{\Lambda})$ and routine $(\boldsymbol{\square})$ dosage groups. Values are expressed as the GMT $\pm \mathrm{SD}$ in $\mu \mathrm{g} / \mathrm{ml} . B$, the influence of maternal diphtheria antibody levels on infant IgG antibody responses. The analysis combines neonatal and routine dosage groups. The high $(\Delta=>$ GMT of cord blood) and low ([] $=\leq$ GMT of cord blood) maternal antibody classes were determined by comparing individual cord blood specimens to the GMT for all cord bloods. Values are expressed as the GMT \pm SD in $\mu \mathrm{g} / \mathrm{ml}$.

at birth (GMT: $1.9 \mu \mathrm{g} / \mathrm{ml} \mathrm{ND}$ group versus $1.1 \mu \mathrm{g} / \mathrm{ml} \mathrm{RD}$ group), at 6 months (GMT: $7.7 \mu \mathrm{g} / \mathrm{ml}$ ND group versus $3.7 \mu \mathrm{g} / \mathrm{ml} \mathrm{RD}$ group), or at 9 months of age (GMT: $10.3 \mu \mathrm{g} / \mathrm{ml} \mathrm{ND}$ group versus $9.68 \mu \mathrm{g} / \mathrm{ml} \mathrm{RD}$ group) (NS, $t$ test).

Tetanus antibody. The analyses of tetanus IgG immune responses were similar to those of diphtheria. There was no difference in antibody levels between the RD and ND groups at 0,6 , or 9 months of age (NS, Rank Sum and $t$ test) (Fig. 2A). The influence of maternal antibody is shown in Figure $2 B$. Data for the vaccine groups were combined and divided into high or low classes based on maternally acquired levels of antibody in cord blood ( $>$ GMT or $\leq$ GMT of cord blood, respectively). There was no significant difference in antitoxin levels between these groups at 6 or 9 months of age.

Finally, by comparing the ND and RD groups in infants with low cord levels of tetanus antibody, we assessed the possibility of tolerance. There were no statistical differences in antibody levels at birth (GMT: $1.4 \mu \mathrm{g} / \mathrm{ml}$ ND group versus $1.1 \mu \mathrm{g} / \mathrm{ml} \mathrm{RD}$ group), at 6 months (GMT: $4.5 \mu \mathrm{g} / \mathrm{ml}$ ND group versus $2.7 \mu \mathrm{g} / \mathrm{ml} \mathrm{RD}$ group), or at 9 months of age (GMT: $15.9 \mu \mathrm{g} / \mathrm{ml}$ ND group versus $13.6 \mu \mathrm{g} / \mathrm{ml} \mathrm{RD}$ group) (NS, $t$ test).

Tetanus subclass antibody. IgG subclass-specific levels of tetanus antibody were measured in specimens obtained at birth, 6 months and 9 months for both the ND and the RD groups (Fig. 

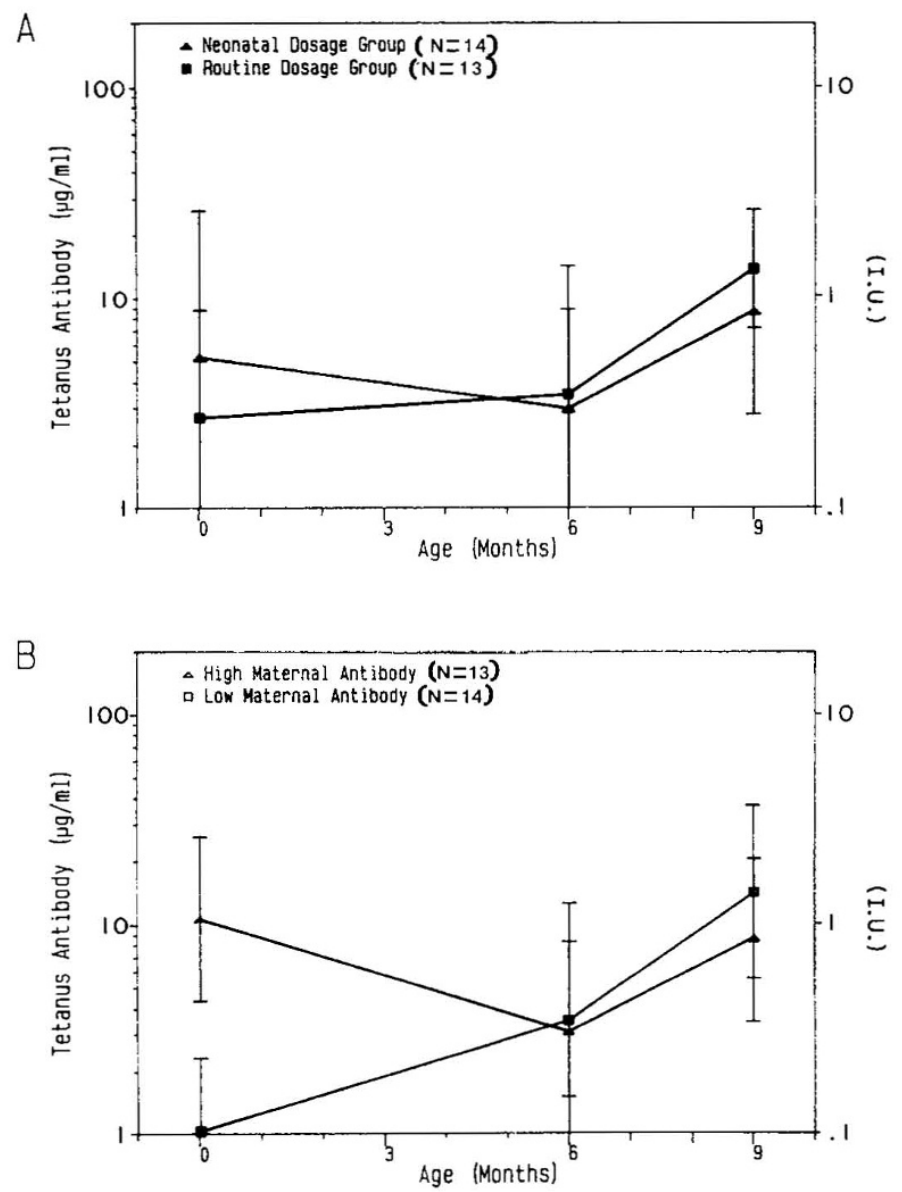

Fig. 2. A, comparison of total tetanus $\mathrm{IgG}$ antibody levels in neonatal $(\triangle)$ and routine ( $\mathbf{\square})$ dosage groups. Values are expressed as the GMT \pm $\mathrm{SD}$ in $\mu \mathrm{g} / \mathrm{ml}$ and IU. $B$, the influence of maternal tetanus antibody levels on infant $\mathrm{IgG}$ antibody responses. The analysis combines neonatal and routine dosage groups. The high $(\Delta,>$ GMT of cord blood) and low ([], $\leq$ GMT of cord blood) maternal antibody classes were determined by comparing individual cord blood specimens to GMT for all cord bloods. Values are expressed as GMT $\pm \mathrm{SD}$ in $\mu \mathrm{g} / \mathrm{ml}$ and $\mathrm{IU}$.

3). The responses for $\mathrm{IgG}-1, \mathrm{IgG}-2$, IgG-3, and $\mathrm{IgG}-4$ were not statistically different between the vaccine groups at any of the time points. For the ND group, the mean increase in antibody at 9 months was 1.7, 2.2, 1.7, and 2.4 times the values at 6 months for IgG-1, IgG-2, IgG-3, and IgG-4, respectively. Correspondingly, for the RD group at 9 months, the mean increases in tetanus antibody level were $2.0,2.5,2.9$, and 3.5 for IgG-1, IgG-2, IgG-3, and IgG-4, respectively. Although there was a tendency for the ND group to have higher cord blood and lower 9 month antibody levels for each of the subclasses these differences were not statistically significant (Fig. 3).

In as much as none of the subclass specific antibody levels differed significantly according to vaccine group, data from the ND and RD groups for each subclass were combined. The data were then divided into high or low levels based on maternally acquired antibodies ( $>$ GMT or $\leq$ GMT of cord blood, respectively). For all subclasses, the infant groups with low cord blood antibody had higher mean serum antibody levels at 6 and 9 months of age than the infant group which had high cord blood antibody levels (Table 1). These differences between groups indicated a trend, although statistical significance at $p=0.056$ level was attained only for IgG-2.

Antitetanus responses were evident in all four IgG subclasses. Subclass responses and total $\mathrm{IgG}$ antibody responses in individual children paralleled one another in every instance. The unique pattern of each infant's subclass and total tetanus responses was partially dependent on the level of maternal antibody. Since each assay was independently quantitated, the absolute values cannot be compared and only relative changes in antibody titer over time are important.

Sequential antibody levels of all subclasses in four infants representing different response patterns are shown in Figure 4. Infants with low cord blood levels universally had a rise in titer at 6 months and most had a further increase at nine months whereas others dropped after the 6-month sample. Those that began with high cord blood level of antibodies generally had a decrease in antibodies at 6 months after which they either continued to decline or, more commonly increased between the 6 and 9 months of age. These patterns were not influenced by neonatal immunization since pattern $\mathrm{A}, \mathrm{B}$, and $\mathrm{C}$ were observed in both the ND and RD infant groups. Pattern D occurred in only one infant who had received neonatal immunization. It should be noted that different standard and positive control sera and different antisera were used for the various subclass assays. Therefore, IgG1 units are not quantitatively comparable to IgG2, IgG3, or IgG4 units, although changes in IgG1 units in a given infant and differences in IgG1 units between different infants are accurately represented. The same is true for antibody units of the other subclasses.

\section{DISCUSSION}

Although immune responses to tetanus and diphtheria antigens can be elicited from birth or before (5), these responses improve with age, especially after the first 2 months of life. Osborn et al. (6) demonstrated this phenomenon for diphtheria and tetanus toxoid in infants ranging in age from birth to 6 months. Di Saint'Agnese (7) and Gaisford et al. (8,) showed that the majority of young infants immunized with DTP beginning in the first week of life subsequently developed protective antibody levels. In our study, we also demonstrated that high levels of antibody can be achieved in infants given an early neonatal dose of diphtheria or tetanus toxoid. Moreover, we found that an extra dose of DTP given to neonates neither enhanced nor diminished their antibody levels to diphtheria or tetanus at 9 months of age.

In addition to a general immaturity of the immune system, another potential immunosuppressing factor in the newborn is the level of passively acquired maternal antibody. Although the mechanism of this suppression is not clear, Wilson and Miles (9) postulated that passively acquired antibody could bind to antigen forming a complex, which might be more readily cleared from the body. Therefore, transplacentally acquired antibodies might diminish the primary immune exposure. Although no studies exist specifically for tetanus toxoid, a suppressive effect of high maternal antibody level on infant immune response to diphtheria toxoid has been shown $(8,11)$. However, this effect on diphtheria immune responses is incomplete and can be overcome with multiple antigenic stimuli. The current immunization schedule at 2, 4, and 6 months has been shown to induce high levels of diphtheria antibody whose final titers are not influenced by passively acquired antibody (12). In our study, by comparing tetanus and diphtheria immune responses according to low or high cord antibody levels, we showed no statistically significant suppressive effect of maternal antibody. However, all infants in our study had detectable diphtheria and tetanus antibody at birth and therefore we cannot extrapolate to the situation in third world countries where a sizeable proportion of newborns have no antibody and are susceptible to tetanus neonatorum. Any subtle diminution of diphtheria, tetanus, and tetanus subclassspecific responses at 6 months of age in subjects with high maternal antibody, was not apparent by 9 months of age.

The concept of immunological immaturity of the newborn is closely linked with that of immunological tolerance. While there are studies about tolerance reported for pertussis vaccination (1, 13), there are little data regarding diphtheria or tetanus toxoid. 

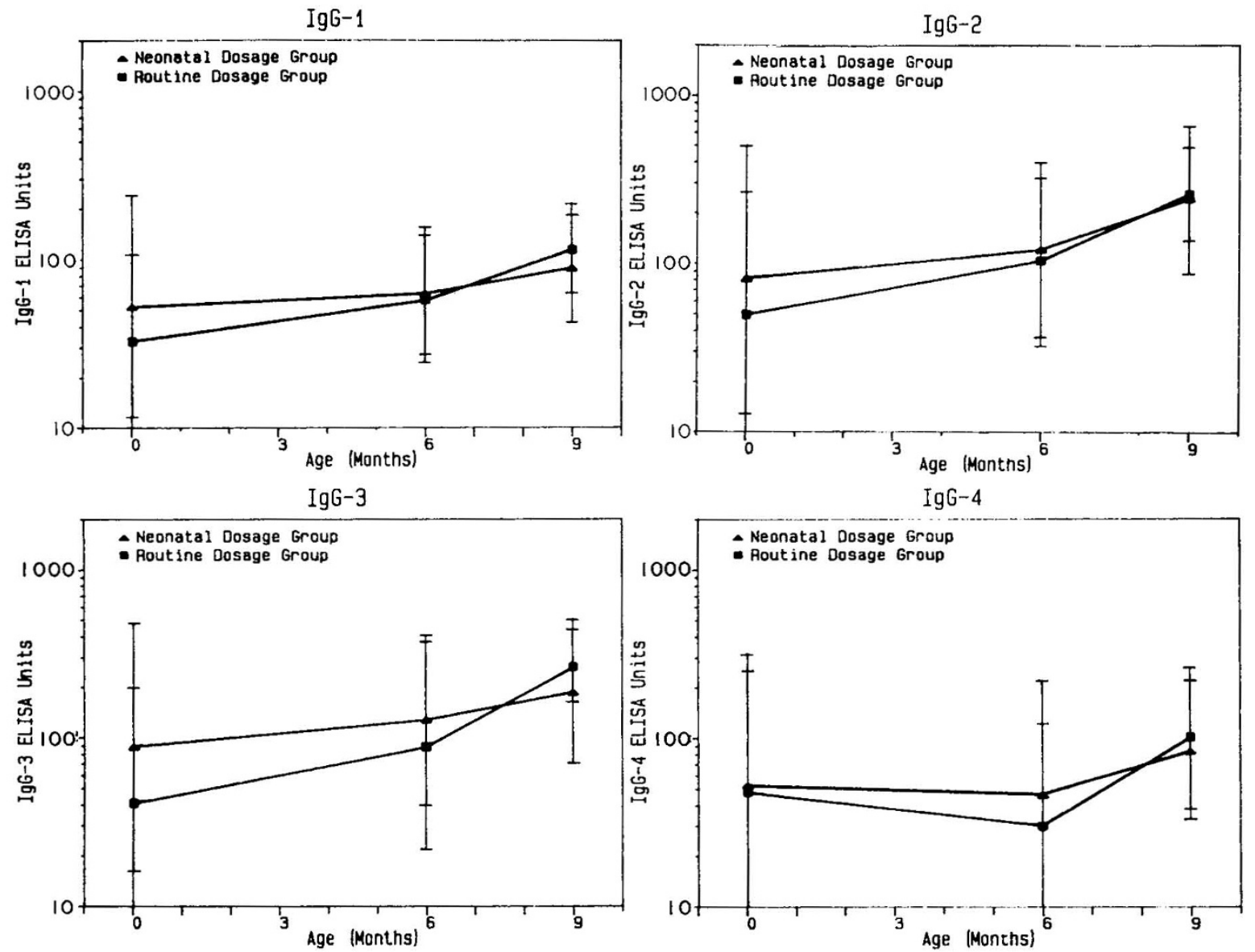

Fig. 3. Comparison of tetanus IgG subclass specific levels in neonatal $(\boldsymbol{\Lambda})(n=14)$ and routine $(\mathbf{\square})(n=13)$ dosage groups. ELISA units are expressed as the GMT \pm SD.

Table 1. Influence of maternal tetanus antibody levels on infant IgG subclass antibody responses*, $\dagger$

\begin{tabular}{|c|c|c|c|c|c|c|}
\hline & \multirow[b]{2}{*}{$\begin{array}{l}\text { Maternal } \\
\text { antibody }\end{array}$} & \multirow[b]{2}{*}{ Cord } & \multicolumn{2}{|c|}{$6 \mathrm{Mo}$} & \multicolumn{2}{|c|}{$9 \mathrm{Mo}$} \\
\hline & & & $\begin{array}{c}\text { Antibody } \\
\text { level }\end{array}$ & $p$ value & $\begin{array}{c}\text { Antibody } \\
\text { level }\end{array}$ & $p$ value \\
\hline $\mathrm{IgG}_{1}$ & $\begin{array}{l}\text { Low } \\
\text { High }\end{array}$ & $\begin{array}{r}15.9 \\
138.3\end{array}$ & $\begin{array}{l}73.6 \\
48.9\end{array}$ & 0.232 & $\begin{array}{r}111.0 \\
81.4\end{array}$ & 0.357 \\
\hline $\mathrm{IgG}_{2}$ & $\begin{array}{l}\text { Low } \\
\text { High }\end{array}$ & $\begin{array}{r}18.3 \\
372.4\end{array}$ & $\begin{array}{r}164.0 \\
68.7\end{array}$ & 0.056 & $\begin{array}{l}284.2 \\
200.3\end{array}$ & 0.285 \\
\hline $\mathrm{IgG}_{3}$ & $\begin{array}{l}\text { Low } \\
\text { High }\end{array}$ & $\begin{array}{r}18.9 \\
333.6\end{array}$ & $\begin{array}{r}159.1 \\
69.4\end{array}$ & 0.106 & $\begin{array}{l}247.1 \\
188.6\end{array}$ & 0.392 \\
\hline $\mathrm{IgG}_{4}$ & $\begin{array}{l}\text { Low } \\
\text { High }\end{array}$ & $\begin{array}{r}13.1 \\
269.0\end{array}$ & $\begin{array}{l}62.1 \\
22.4\end{array}$ & 0.084 & $\begin{array}{l}94.6 \\
88.2\end{array}$ & 0.838 \\
\hline
\end{tabular}

* In all subclasses, the infants with low cord blood antibody had higher mean serum antibody levels at both 6 and 9 months of age than the infants who had high cord blood antibody levels. Utilizing Student's $t$ test, the differences often approach but only attain statistical significance for $\operatorname{lgG} 2$ at 6 months of age.

† Values represent geometric mean's of ELISA units. Low maternal antibody refers to $\leq$ geometric mean of combined ND and RD group. High maternal antibody refers to $>$ geometric mean of combined ND and RD group.

In the present study, we compared the immune responses of infants in the ND and RD groups with low cord tetanus and diphtheria antibody levels. We selected these infants because an adverse effect of neonatal pertussis immunization was reported in this group. However, similar diphtheria and tetanus antibody levels at 6 and 9 months were achieved for both ND and RD vaccine groups. Thus, tolerance for diphtheria or tetanus antigen was not demonstrated.

It was of interest to determine whether all four IgG subclasses contributed to the total tetanus IgG antibody response. IgG1 is generally considered to be the predominant subclass contributing to tetanus antibody $(14,16)$. In this study, we demonstrated subclass responses to the tetanus toxoid component of the DTP vaccine for all four subclasses. We chose not to quantitate absolute levels of antibody for each subclass by the method of Zollinger, because it has not yet been shown that this is equivalent to quantitative precipitin assays for subclass antibodies. A complicating factor is that there is insufficient precipitating antibody for some subclasses to perform quantitative precipitin tests. Since we were primarily interested in immune responses rather than absolute antibody levels, we used a high titered serum to construct a standard curve for each subclass. Therefore, we could not determine in this study what proportion of the total IgG antibody was comprised of each subclass.

We found that a given infant displayed a similar sequential pattern for each of the four subclasses which also paralleled the total IgG immune response pattern. This suggests that the mechanisms regulating the four subclass antibody responses are similar or identical in infants who are functionally competent to synthesize all four types of antibody. Thus regulation of antiprotein antibodies in infancy seems to relate more to class-specific than to subclass-specific determinants.

In conclusion, the IgG antibody responses at 6 and 9 months of age in infants receiving an additional early neonatal immunization with diphtheria and tetanus toxoid were equivalent to those who received only routine immunizations. There was no 

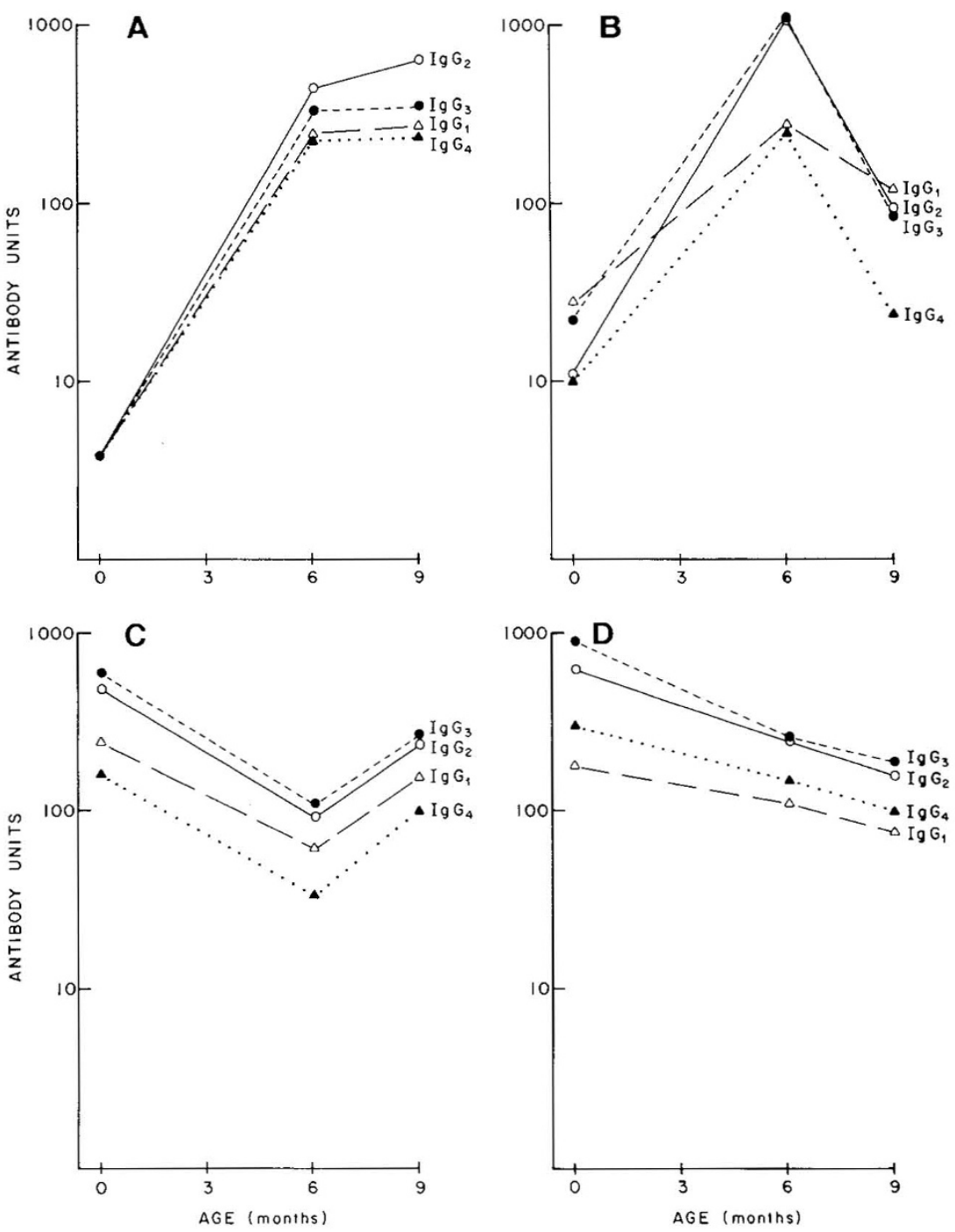

Fig. 4. Patterns of antibody response to tetanus toxoid in four representative infants. Infant A had low cord blood titers and all four subclass antibodies rose at 6 months and continued to rise until 9 months of age. Infant B started with low cord blood titers and had rising titers at 6 months of age but a drop at 9 months. Infant $C$ initially had high cord blood antibodies and had drop of all four subclass antibodies at 6 months, followed by a rise at 9 months. Infant D had high cord blood titers, a decrease at 6 months, and a further decrease at 9 months of age.

significant difference in subclass levels by 9 months of age. The subclass responses to tetanus toxoid were mirrored by the total IgG response. All infants, regardless of the number of DTP doses or the level of maternal antibody, had definitive immune responses to diphtheria and tetanus toxoid by 9 months of age.

Acknowledgment. The authors thank Terrance Payne and Susan Everett for assistance with the clinical studies, Kelly Burkart for laboratory assistance, Ching-Yin Chiu for assistance with analysis, and Mary Magee for secretarial assistance.

Diphtheria and tetanus toxoid was kindly provided by Dr. George Siker at the Massachusetts Biologic Laboratories.

\section{REFERENCES}

1. Baraff LJ, Leake RD, Burstand G, Payne T, Cody C, Manclark C, St. Geme J 1984 Immunologic response to early and routine DTP immunization in infants. Pediatrics 73:37-42

2. Zollinger W, Bostego JW 1981 A general approach to standardization of the solid-phase radioimmunoassay for quantitation of class-specific antibodies. J Immunol Methods 46:129-140

3. Snedecor GW, Cochran WG 1967 Statistical Methods, 6th ed. Iowa State University Press, Ames, IA

4. Bock RD 1975 Multivariate Statistical Methods in Behavioral Research McGraw-Hill Book Co, New York

5. Gill T, Repetti C, Metlaz L, Rabin B, Taylor F, Thompson D, Cortese A 1983
Transplacental immunization of the human fetus to tetanus by immunization of the mother. J Clin Invest 72:987-996

6. Osborn JJ, Daniels J, Julia JF 1952 Studies of the immunology of the newborn infant. I. Age and antibody production. Pediatrics 9:736-744

7. Di Sant'Agnese PA 1949 Combined immunization against diphtheria, tetanus and pertussis in newborn infants I. Production of antibodies in early infancy. Pediatrics 3:20-33

8. Gaisford W, Feldman GV, Perkins FT 1960 Current immunization problems. J Pediatr 56:319-330

9. Wilson GS, Miles AA 1955 Topley and Wilson's Principles of Bacteriology and Immunization, 4th ed. London, Arnold

10. Cooke JV, Holowach J, Atkins JE, Powers J 1948 Antibody formation in early infancy against diphtheria and tetanus toxoids. J Pediatr 33:141-146

11. Smith R 1960 Immunity in infancy. Pediatr Clin North Am 7:269-293

12. Nelson LA, Peri BA, Reiger CHL, Newcomb RW, Rothberg RM 1977 Immunity to diphtheria in an urban population. Pediatrics 61:703-710

13. Provenzano WR, Wetterlow LJ, Sullivan CL 1965 Immunization and antibody response in the newborn infant. I. Pertussis innoculation within 24 hours of birth. N Engl J Med 273:959-965

14. Yount WJ, Dorner MM, Kunkel HG, Kabat EA 1968 Studies on human antibodies VI. Selective variations in subgroup composition and genetic markers. J Exp Med 127:663-646

15. Stevens R, Dichek D, Keld B, Heiner DC $1983 \mathrm{IgG}_{1}$ is the predominant subclass of in vivo- and in vitro-produced antitetanus toxoid antibodies and also serves as the membrane IgG molecule for delivering inhibitory signals to antitetanus toxoid antibody-producing B cells. J Clin Immunol 3:65-69

16. Seppälä HJT, Routonen N, Sarnesto A, Mattila PA, Mäkelä O 1984 The percentages of six immunoglobulin isotypes in human antibodies to tetanus toxoid: standardization of isotype specific second antibodies in solid-phase assay. Eur J Immunol 14:868-875 